\title{
Effect of glucocorticoid receptor gene polymorphisms on asthma phenotypes
}

\author{
MICHAŁ PANEK $^{1 *}$, TADEUSZ PIETRAS $^{2 *}$, ARTUR FABIJAN $^{3}$, MACIEJ MIŁANOWSKI $^{3}$, \\ ŁUKASZ WIETESKA ${ }^{4}$, PAWEŁ GÓRSKI ${ }^{2}$, PIOTR KUNA ${ }^{1}$ and JANUSZ SZEMRAJ ${ }^{4}$ \\ Departments of ${ }^{1}$ Internal Medicine, Asthma and Allergy and ${ }^{2}$ Pneumology and Allergology, \\ ${ }^{3}$ Student Research Group at the Department of Pneumology and Allergology, Medical University of Lodz, \\ Lodz 90-153; ${ }^{4}$ Department of Medical Biochemistry, Medical University of Lodz, Lodz 92-215, Poland
}

Received June 29, 2012; Accepted October 17, 2012

DOI: $10.3892 /$ etm.2012.809

\begin{abstract}
The clinical presentation of asthma results from complex gene-gene and gene-environment interactions. The natural variability of the DNA sequence within the $\mathrm{NR} 3 \mathrm{Cl}$ gene affects the activity of glucocorticoid receptors (GCRs). The NR3Cl gene is localized on chromosome 5q31-q32. The gene coding for the GCR comprises nine exons. The structural domains of the GCR determine the biological functions of the functional domains. The observed resistance to glucocorticosteroids and the normal metabolic profile of Tth1111 single nucleotide polymorphism (SNP) carriers is due to the ER22/23EK polymorphism that is present in them. BclI polymorphism significantly affects the process of alternative $N R 3 C 1$ gene splicing and within that mechanism increases the
\end{abstract}

Correspondence to: Professor Janusz Szemraj, Department of Medical Biochemistry, Medical University of Lodz, Mazowiecka 6/8, Lodz 92-215, Poland

E-mail: jszemraj@csk.am.lodz.pl

*Contributed equally

Abbreviations: $\mathrm{ACT}^{\mathrm{TM}}$, Asthma Control Test; AF, activation function; ATS, American Thoracic Society; CI, confidence interval; DBD, DNA-binding domain; EAACI, European Academy of Allergy and Clinical Immunology; EDTA, ethylenediaminetetraacetic acid; ERS, European Respiratory Society; $\mathrm{FEV}_{1}$, forced expiratory volume in $1 \mathrm{sec}$; FVC, forced vital capacity; GCR, glucocorticoid receptor; GCs, glucocorticoids; GINA, Global Initiative For Asthma; GRE, glucocorticoid response element; HGNC, HUGO Gene Nomenclature Committee; HRM, high resolution melting; LBD, ligand-binding domain; mRNA, messenger RNA; NCBI, National Center for Biotechnology Information; NLS, nuclear localization sequence; $\mathrm{NR} 3 \mathrm{Cl}$, nuclear receptor subfamily 3 , group $\mathrm{C}$, member 1 (glucocorticoid receptor); NSAIDs, non-steroidal anti-inflammatory drugs; OR, odds ratio; SD, standard deviation; PCR, polymerase chain reaction; RFLP, restriction fragment length polymorphism; SNP, single nucleotide polymorphism.

Key words: NR3C1 gene, glucocorticoid receptor, glucocorticoid receptor gene polymorphisms, single nucleotide polymorphism, restriction fragment length polymorphism, inflammation, asthma sensitivity to glucocorticoids (GCs). A total of 451 subjects were enrolled in the present study, including 235 qualified to the group of bronchial asthma patients. A group of 216 healthy participants with no history of asthma or atopic conditions was qualified for the study. Genotyping was accomplished using the polymerase chain reaction-restriction fragment length polymorphism (PCR-RFLP) and PCR-high resolution melting (HRM) methods. No statistically significant differences were observed in the frequency of Tth111I, BclI and ER22/23EK polymorphisms of the NR3Cl gene when comparing mild, moderate and severe asthma vs. the control group. Investigative analyses demonstrated statistically significant correlations for alleles and genotypes of Tth111I polymorphism of the NR3CI gene between healthy subjects and patients with severe asthma characterized by a control profile corresponding to an Asthma Control Test $(\mathrm{ACT})^{\mathrm{TM}}$ score $\geq 20$. It was established that only the Tth111I polymorphism of the NR3Cl gene plays an important role in the pathogenesis of chronic bronchitis leading to the development of asthma with both allergic and non-allergic etiology.

\section{Introduction}

Bronchial asthma is a chronic disease determined by multiple factors, with pathogenesis involving many cell types and substances secreted by them. The clinical presentation results from complex gene-gene and gene-environment interactions (1-4). One of the genes involved in the pathogenesis and clinical presentation of asthma is the NR3Cl gene [(official symbol: NR3Cl provided by the HUGO Gene Nomenclature Committee (HGNC); official full name: nuclear receptor subfamily 3 , group $\mathrm{C}$, member 1 (glucocorticoid receptor) provided by HGNC)], which encodes the glucocorticoid (GC) receptor (GCR) (5).

The NR3C1 gene is localized on chromosome 5q31-q32 and consists of nine exons [National Center for Biotechnology Information (NCBI) Reference Sequence: NM_000176] $(5,6)$. Exon 1 has seven basic transcriptional variants. Exons from 2 to 8 function as the core sequences of the $N R 3 C 1$ gene (7). Exon 9 determines two alternative splicing variants. The product of $N R 3 C 1$ gene expression is mRNA, which constitutes the basis for GCR isoforms formed as a result of alternative splicing 
(GCR $\alpha$, GCR $\beta$, GCR $\delta$, GCR $\gamma$ and GCR-P), among which only the $\alpha$ isoform is active $(4,8,9)$. GCR $\beta$ is able to inhibit the signal pathway of isoform $\alpha$ and lead to impaired sensitivity to glucocorticosteroids.

The GCR comprises 777 amino acids and five functional domains: activation function 1 (AF1), structural domain A/B; DNA-binding domain (DBD), structural domain C; nuclear localization sequence (NLS), structural domain D; ligandbinding domain (LBD), structural domain E; and activation function 2 (AF2), structural domain F (4,10-16). Figs. 1 and 2 show the organization of the $\mathrm{NR} 3 \mathrm{Cl}$ gene structure and relations between the structural and functional domains of the GCR.

The structure and biological activity of GCR domains is determined by the structure and nucleotide composition, among others, of the appropriate/corresponding exons of the $N R 3 C l$ gene. The interactions of the GC/GCR complex and GC response element (GRE) may lead to selective activation or suppression of the target genes. The effect of GCs on the synthesis of proteins is determined by interactions with transcriptional enhancement sequences (GRE-positive) or transcriptional silencing sequences (GRE-negative) $(4,9,10,14,17,18)$. The GCR interacts directly with expression coactivators and corepressors for numerous genes. Therefore, the GCR is a particularly important element determining appropriate patient responses to exogenous GCs, which are the most important anti-inflammatory agents for controlling the course of bronchial asthma $(4,13,14,19-21)$.

Nucleotide changes in the studied gene DNA (single nucleotide polymorphisms; SNPs) may have a regulatory effect on expression and lead to changes in the RNA splicing process. Polymorphisms are responsible for modifications of the secondary and tertiary domain structures in the GCR, as well as for disturbances of transcription initiation and stability of the mRNA for the GCR $(4,14,22-24)$. The locations of $\mathrm{NR} 3 \mathrm{Cl}$ gene polymorphisms are shown in Fig. 3 .

Polymorphism Tth111I (rs10052957) is located in the area of the $\mathrm{NR} 3 \mathrm{Cl}$ gene promoter and localized in its transcript at position -13-6284. The SNP is situated in a large 27-kb intron just above the site of transcription initiation (between exons Ex $1 \mathrm{C}$ and $\mathrm{Ex} 1 \mathrm{H}$ ) and 3807 bp above the first site where transcription in exon 2 begins. It causes a $\mathrm{C}>\mathrm{T}$ substitution in the promoter region (25). It is considered that the observed resistance to glucocorticosteroids and the normal metabolic profile of Tth111I SNP carriers is due to ER22/23EK polymorphism that is present in them (24-27).

Polymorphism BclI (rs41423247) is located in intron 2 of the $\mathrm{NR} 3 \mathrm{Cl}$ gene and localized in its transcript at position 1184+646. Intron 2 (B) is situated between exons 2 and 3 of the $\mathrm{NR} 3 \mathrm{Cl}$ gene. It causes a $\mathrm{C}>\mathrm{G}$ substitution in the promoter region. $B c l$ I SNP is localized 646 nucleotides above exon 2 of the $N R 3 C l$ gene $(6,28-30) . B c l$ l polymorphism significantly affects the process of alternative $N R 3 C l$ gene splicing and within that mechanism increases the sensitivity to GCs. The above concerns both $B c l$ I CG and $B c l$ I GG $(24,25,31)$.

Polymorphism ER22/23EK is located in exon 2 of the $N R 3 C 1$ and comprises two nucleotide transitions coupled with each other in codons 22 and 23 (24). A latent transition in codon 22 causes no amino acid substitution $(\mathrm{G}>\mathrm{A}$; position 198; codon GAG and GAA code for glutamic acid), whereas the transition in codon 23 causes substitution of arginine with lysine (G>A; AGG $>$ AAG; position 200), which may consequently lead to a change in the tertiary structure of the GCR domain responsible for activation of transcription. Both polymorphisms are completely coupled with each other $(9,24,32)$. The mechanism explaining GC resistance is the effect of ER22/23EK on the GCR $\alpha-A / G C R \alpha-B$ ratio $(24,27,16)$. The SNP correlates with increased production of the GCR $\alpha$-B form, which results in decreased receptor capability of target gene transactivation $(24,26,27)$.

The aim of the present study was to assess the effect of the selected $\mathrm{NR} 3 \mathrm{Cl}$ gene polymorphisms on the level of asthma control, as well as to identify in additional investigative studies their role in the determination of disease presentation phenotypes in particular patient groups.

\section{Materials and methods}

Patients and control subjects. Bronchial asthma patients were recruited from among those treated in the Department of Internal Medicine, Asthma and Allergy of N. Barlicki Memorial University Teaching Hospital No. 1, Lodz, Poland, Department of Pneumology and Allergology of N. Barlicki Memorial University Teaching Hospital and Specialist Outpatient Department of Pulmonary Diseases and Allergology at N. Barlicki Memorial University Teaching Hospital No. 1 of the Medical University of Lodz, Poland. Healthy volunteers from the general population were included in the study. They were selected on a random basis.

In total, 451 subjects were enrolled, including 235 qualified to the group of bronchial asthma patients. The inclusion criteria were: i) the patient's informed consent to participate in the study was given and ii) appropriate spirometry results were obtained enabling the correct interpretation and diagnosis of asthma according to a report from The Global Initiative For Asthma (GINA) $(1,2)$. Patients were excluded from the study on the basis of the following criteria: treatment with rifampicin, phenobarbital, phenytoin and/or ephedrine, and exacerbation of the disease due to infections. The bronchial asthma group comprised $62.6 \%$ (147) females and $37.4 \%$ (88) males. The mean age was 48.8 years [standard deviation $(\mathrm{SD}) \pm 16.0$ ], with a range of 19-82 years. Detailed parameters of the bronchial asthma patients are shown in Table I.

The control group comprised 216 healthy subjects. The subjects qualified to the control group met all the following criteria: i) no data from subjective and objective examinations confirming the presence of bronchial asthma, other pulmonary diseases, allergy, atopy and hypersensitivity to non-steroidal anti-inflammatory drugs (NSAIDs); ii) no spirometry results confirming airway obstruction; iii) negative results of skin prick tests with common allergens; iv) no first-degree relatives with asthma, allergy or atopy; and v) no treatment with rifampicin, phenobarbital, phenytoin and ephedrine.

The control group comprised $65.7 \%$ (142) females and $34.3 \%$ (74) males. The mean age was 45.7 years. ( $\mathrm{SD} \pm 16.3$ ), with a range of 18-85 years.

Spirometry. Functional tests of the respiratory system were carried out according to the standards of the European Respiratory Society (ERS) and American Thoracic Society (ATS) (33). 


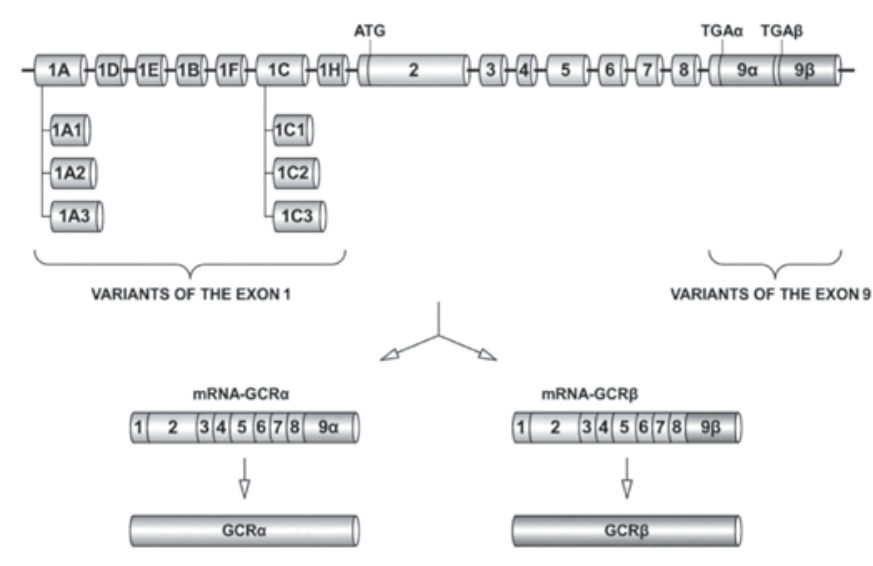

Figure 1. Organization and expression of the $\mathrm{NR} 3 \mathrm{Cl}$ gene. The gene coding for the glucocorticoid receptor (GCR) is made up of nine exons. Exon 1 has seven basic transcriptional variants (Ex1A, Ex1D, Ex1E, Ex1B, Ex1F, Ex1C and Ex1H). The core exons of the gene are those from Ex2 to Ex8. Exon 9 determines two alternative splicing variants: isoform $\alpha$ and isoform $\beta$ of the GCR. Detailed description and relevant literature in the text. Authors' own elaboration based on $(8,15,16)$.

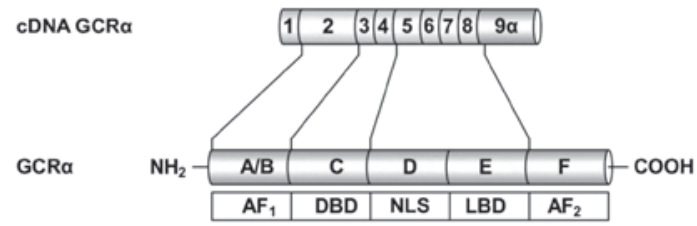

Figure 2. Structural and functional domains of the glucocorticoid receptor (GCR). The structural domains of the GCR: A/B, C, D, E and F determine the biological functions of the functional domains: activation function 1 (AF1), DNA-binding domain (DBD), nuclear localization sequence (NLS), ligandbinding domain (LBD) and AF2. Detailed description and relevant literature in the text. Authors' own elaboration based on $(4,8,9,15)$.

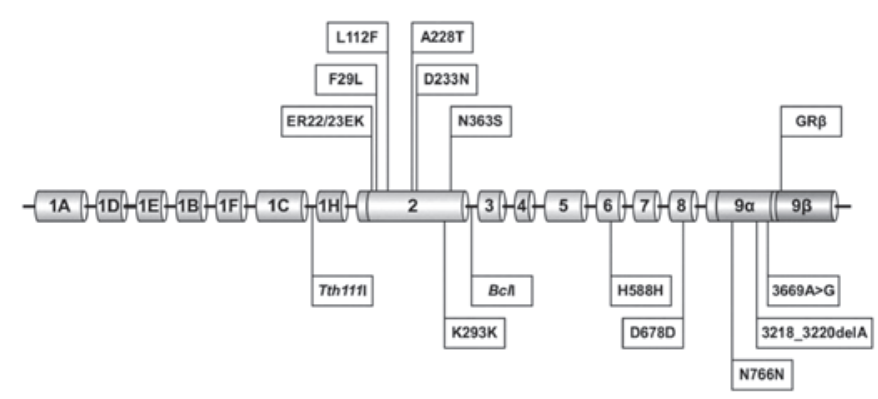

Figure 3. $\mathrm{NR} 3 \mathrm{Cl}$ gene polymorphisms. The upper part of the diagram presents single nucleotide polymorphisms (SNPs) causing amino acid variability. The lower part contains polymorphisms causing no changes in the glucocorticoid receptor structure. SNP positioning in the $\mathrm{NR} 3 \mathrm{Cl}$ according to the National Center for Biotechnology Information (NCBI) reference sequence: NM_000176. Detailed description and relevant literature in the text. Authors' own elaboration based on $(25,26)$.

Detailed descriptive statistics for the patient group and the control arm, including spirometry parameters, are shown in Table II.

Asthma control test. The level of asthma control was assessed using the Asthma Control Test (ACT ${ }^{\mathrm{TM}}$ ), developed by Nathan et $a l$ and recommended by the GINA report. The bronchial
Table I. Characteristics of patients with asthma, including the degree of disease severity.

\begin{tabular}{lrr}
\hline $\begin{array}{l}\text { Classification of asthma } \\
\text { according to severity }\end{array}$ & $\mathrm{N}$ & $\%$ \\
\hline Asthma & 235 & 100.00 \\
Non-severe & 151 & 64.26 \\
Severe & 84 & 35.74 \\
Chronic mild & 35 & 14.90 \\
Chronic moderate & 116 & 49.36 \\
Chronic severe & 84 & 35.74 \\
\hline
\end{tabular}

asthma control level was calculated on the basis of the following patient results obtained by ACT: 0-19 points, no asthma control; 20-24 points, partially controlled asthma; and 25 points, well-controlled asthma $(1,2,4,34)$.

Skin-prick tests. Skin-prick tests were performed according to the guidelines of European Academy of Allergy and Clinical Immunology (EAACI) (35).

Isolation of DNA. DNA was isolated from whole blood sampled into ethylenediaminetetraacetate (EDTA) by a spin column method using a QIAamp DNA Blood Mini kit (Qiagen, Hilden, Germany) according to the guidelines provided by the manufacturer.

NR3Cl gene Tth111I polymorphism genotyping by the PCR-HRM method. The Tth111I polymorphism of the NR3Cl gene was genotyped using the PCR-HRM method with application of the LightScanner ${ }^{\circledR} 32$ system (Idaho Technology, Inc., Salt Lake City, UT, USA). Exponential amplification of DNA segments for Tth111I polymorphism was carried out using forward (5'-GGA TGA ATC CCT ATC TGA GTG-3') and reverse (5'-GGC CAC AAC AAT AAC CCA GTA-3') primers according to standard PCR protocols. Primer binding to complementary DNA matrix sites was conducted at $58^{\circ} \mathrm{C}$.

The first stage of HRM analysis involved amplification of the investigated DNA fragment containing the analyzed Tth111I SNP on a 1:50 matrix using forward (5'-GCA GAG GTG GAA ATG AAG GTG-3') and reverse (5'-GGA GTG GGA CAT AAA GCT ATG ACA-3') primers, followed by denaturation and slow renaturation to form a heteroduplex. At the last stage, the mixture was subjected to precise denaturation in the presence of intercalating stain, and the identification of DNA fragments (Tth111I SNP) was based on the analysis of melting curves. The LightScanner ${ }^{\circledR}$ High Sensitivity Master Mix (Idaho Technology, Inc.) was used for the reaction. This is a specialized master mix containing LCGreen Plus ${ }^{\circledR}$ dye and internal temperature calibrators. The obtained product was subjected to internal control using a molecular probe with a C3-labeled carbon at the 3'-terminal portion [labeled, 3'-blocked oligonucleotide; 5'-ATG TAT TCA GAC TCA GTC AAG GCA AGG ACC $\left.\mathrm{T}(\mathrm{SpcC} 3)-3^{\prime}\right]$ (36-40). The selected SNP samples were verified by sequencing. Fig. 4 presents the melting curves for the probe and amplicon segment DNA fragments of the Tth111I SNP. 
Table II. Descriptive statistics of the analyzed parameters in control and case (general asthma population) groups in the present study.

\begin{tabular}{|c|c|c|}
\hline \multirow[t]{2}{*}{ Parameter } & \multicolumn{2}{|c|}{ Group } \\
\hline & Controls & Asthma patients \\
\hline \multicolumn{3}{|l|}{ Number } \\
\hline $\mathrm{n}$ & 216 & 235 \\
\hline $\mathrm{M} / \mathrm{F}(\%)$ & $74(34.3) / 142(65.7)$ & $88(37.4) / 147(62.6)$ \\
\hline \multicolumn{3}{|c|}{ Age (years) } \\
\hline Mean & 45.7 & 48.8 \\
\hline $\mathrm{SD}$ & 16.3 & 16.0 \\
\hline Median & 47.0 & 51.0 \\
\hline Mode & 23.0 & 52.0 \\
\hline \multicolumn{3}{|c|}{$\mathrm{FEV}_{1}$ (liters) } \\
\hline Mean & 3.0 & 2.2 \\
\hline SD & 0.8 & 0.9 \\
\hline Median & 2.9 & 2.2 \\
\hline Mode & 2.7 & 2.4 \\
\hline \multicolumn{3}{|l|}{$\mathrm{FEV}_{1}(\%)$} \\
\hline Mean & 96.1 & 72.7 \\
\hline $\mathrm{SD}$ & 12.6 & 19.8 \\
\hline Median & 96.0 & 74.0 \\
\hline Mode & 94.5 & 90.0 \\
\hline \multicolumn{3}{|c|}{$\mathrm{FEV}_{1} / \mathrm{FVC}(\%)$} \\
\hline Mean & 79.0 & 66.3 \\
\hline $\mathrm{SD}$ & 6.1 & 12.0 \\
\hline Median & 78.6 & 66.9 \\
\hline Mode & 78.5 & 70.7 \\
\hline \multicolumn{3}{|c|}{ FVC (litres) } \\
\hline Mean & 3.8 & 3.3 \\
\hline $\mathrm{SD}$ & 1.0 & 1.1 \\
\hline Median & 3.6 & 3.2 \\
\hline Mode & 3.5 & 2.3 \\
\hline \multicolumn{3}{|l|}{ FVC $(\%)$} \\
\hline Mean & 102.7 & 91.4 \\
\hline SD & 14.9 & 17.5 \\
\hline Median & 101.0 & 93.0 \\
\hline Mode & 101.0 & 93.0 \\
\hline
\end{tabular}

M, male; F, female; SD, standard deviation; $\mathrm{FEV}_{1}$, forced expiratory volume in $1 \mathrm{sec}$; FVC, forced vital capacity.

Fig. 5 shows the probe normalization process with comparison of the denaturation curves and automatic identification of genotypes on the basis of differences in the melting temperature (GG and AA homozygotes) and denaturation curve shapes (AG heterozygotes) for Tth111I polymorphism.

Fig. 6 shows the amplicon normalization process with comparison of the denaturation curves and automatic identification of genotypes on the basis of differences in the melting temperature (GG and AA homozygotes) and denaturation curve shapes (AG heterozygotes) for Tth111I polymorphism.

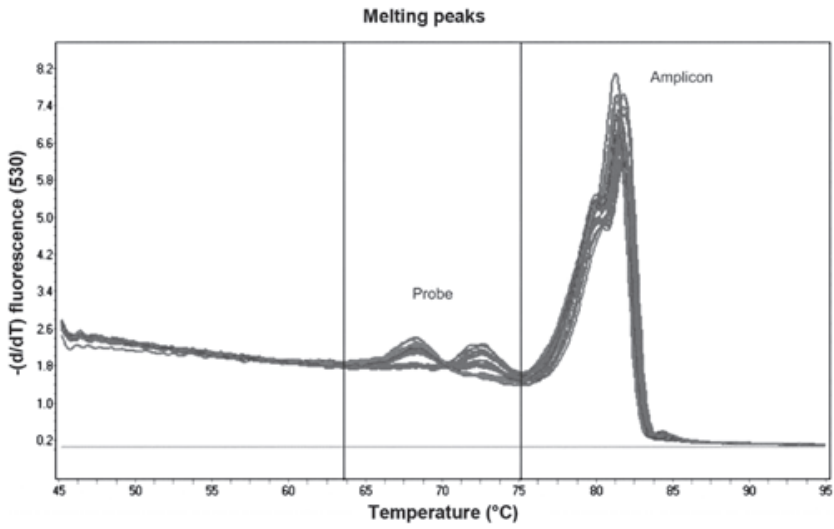

Figure 4. Melting curves obtained for the Tth111I SNP over the entire temperature range. Probe-target melting was observed between $64-75^{\circ} \mathrm{C}$, while the amplicon melting occurred between $76-86^{\circ} \mathrm{C}$.

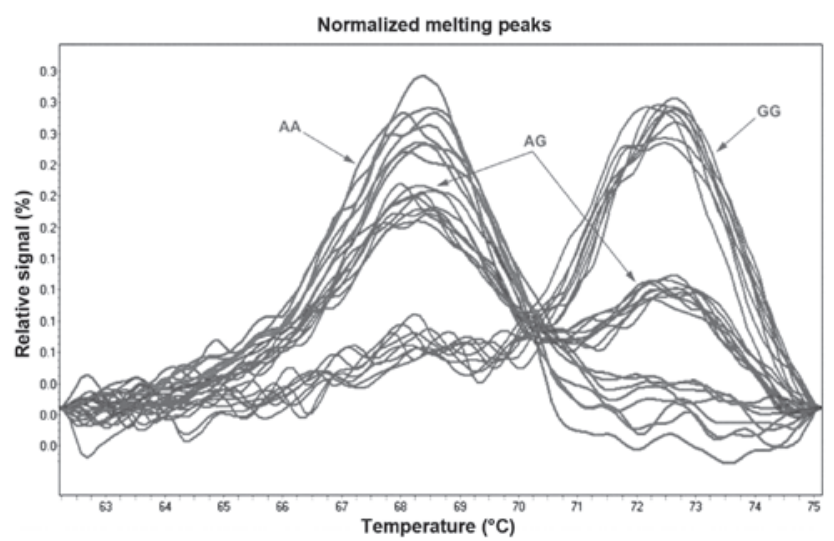

Figure 5. Normalized melting peaks for Tth111I polymorphism shown using unlabelled Luna Probes. The melting curves highlight homozygous mutation, heterozygous and wild-type.

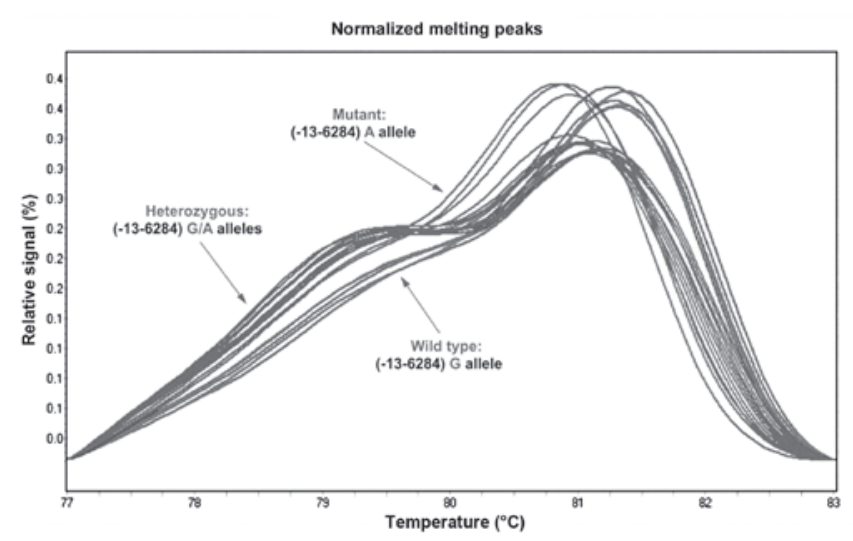

Figure 6. Normalized and temperature-shifted melting curves for Tth1111 polymorphism. The melting curves depict homozygous mutation (AA), heterozygous (GA) and wild type (GG).

Genotyping of BclI and ER22/23EK polymorphisms of the NR3Cl gene using the PCR-RFLP method. Amplification of the DNA fragment containing $B c l$ polymorphism of the $N R 3 C 1$ gene was conducted using primers with the following sequences: forward (5'-GAG AAA TTC ACC CCT ACC 


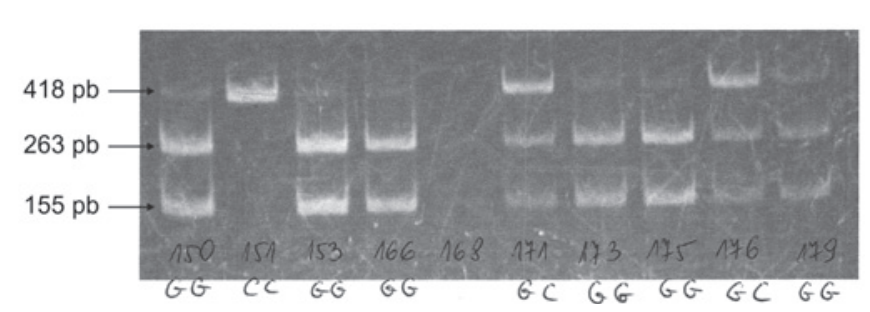

Figure 7. Detection of $B c l$ I polymorphism of the $N R 3 C 1$ gene using polymerase chain reaction-restriction fragment length polymorphism (PCR-RFLP) analyses.

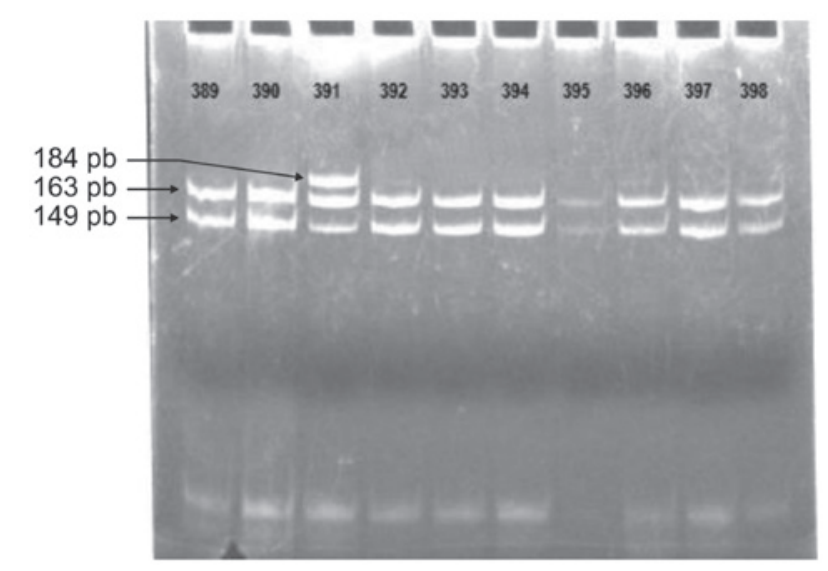

Figure 8 . Detection of ER22/23EK polymorphism using polymerase chain reaction-restriction fragment length polymorphism (PCR-RFLP) analyses of the $N R 3 C l$ gene.

AAC-3') and reverse (5'-AGA GCC CTA TTC TTC AAA CTG-3'), according to standard PCR protocols (41). Primer binding to complementary DNA matrix sites was conducted at $56^{\circ} \mathrm{C} . \mathrm{BclI}$ restriction enzyme (Fermentas International Inc., Burlington, ON, Canada) was used for digestion of the amplification product containing the $B c l$ I polymorphism (41). Hydrolysis of the PCR product with the restriction enzyme was conducted for $24 \mathrm{~h}$ at $55^{\circ} \mathrm{C}$. DNA fragments containing 263 and $151 \mathrm{bp}$ identified as a set of representative, typical (wild type) alleles were obtained, as well as segments with 418, 263 and $155 \mathrm{bp}$. The RFLP product of 418-bp length was identified as a set of polymorphic alleles (41). RFLP products were separated by electrophoresis on $8 \%$ polyacrylamide gel, stained with ethidine bromide and observed in UV light (Image Master, Pharmacia Biotech, Uppsala, Sweden). Fig. 7 presents genotyping of the $\mathrm{BclI}$ polymorphism of the $\mathrm{NR} 3 \mathrm{CI}$ gene using the RFLP method with $B c l$ I restrictase.

Amplification of the DNA fragment containing ER22/23EK polymorphism of the NR3C1 gene was conducted using primers with the following sequences: forward (5'-TGC ATT CGG AGT TAA CTA AAA-3') and reverse (5'-ATC CCA GGT CAT TTC CCA TCA-3') (41). Primer binding to complementary DNA matrix sites was conducted at $56^{\circ} \mathrm{C}$. $\mathrm{MnlI}$ restriction enzyme (Fermentas International) was used for digestion of the amplification product containing the ER22/23EK polymorphism (41). Hydrolysis of the PCR product with the restriction enzyme was conducted for $24 \mathrm{~h}$ at $37^{\circ} \mathrm{C}$. DNA fragments with 149 and $163 \mathrm{bp}$ (and shorter fragments containing 50, 49 and $35 \mathrm{bp}$ ) were obtained as a set of
Table III. Comparative analysis of NR3C1 gene Tth111I polymorphism frequency among asthma patients taking into consideration the disease control level based on Asthma Control Test $(\text { ACT })^{\mathrm{TM}}$ scores $(<20$ vs. $\geq 20)$.

\begin{tabular}{lccc}
\hline & [AA] vs. [AG] & {$[\mathrm{AA}]$ vs. [GG] } & [AA] vs. [AG+GG] \\
\hline OR & 0.275 & 0.344 & 0.301 \\
$\mathrm{CI}$ & $0.114-0.663$ & $0.138-0.858$ & $0.129-0.703$ \\
$\mathrm{Chi}^{2}$ & 8.91 & 5.46 & 8.36 \\
P-value & 0.008 & 0.057 & 0.011 \\
\hline
\end{tabular}

OR, odds ratio; CI, confidence interval.

representative, typical (wild-type) alleles, whereas segments of 163 and $184 \mathrm{bp}$ (and shorter fragments containing 50 and $49 \mathrm{bp}$ ) comprised a set of polymorphic alleles (41). RFLP products were separated by electrophoresis on $8 \%$ polyacrylamide gel, stained with ethidine bromide and observed in UV light (Image Master; Pharmacia Biotech). Fig. 8 presents the genotyping of the ER22/23EK polymorphism of the NR3Cl gene using the RFLP method with $M n l$ I restrictase.

Statistical analysis. Statistical calculations were carried out with a significance level of 0.05 using two-tailed tests. Correlations between NR3Cl gene polymorphisms and asthma control levels were analyzed using the logistic regression model. The differences among the three genotypes were tested and the test for a linear trend was performed. The applied tests were based on the likelihood ratio. Statistical conclusions were based on tests for the linear trend due to their higher power. Bonferroni correction was also applied to the three polymorphisms tested. The odds ratios (ORs) as a measure of relative risk, and their $95 \%$ confidence intervals (CIs) were also calculated with a logistic regression model. The remaining correlations were tested using the $\mathrm{Chi}^{2}$-Pearson test. Furthermore, Hardy-Weinberg hypothesis concerning the equilibrium for allele distribution with respect to Tth111I, $B c l$ I and ER22/23EK polymorphisms of the NR3Cl gene was tested using the tests available on-line at the website of the Institut für Humangenetik Technisches Universität München, Helmholtz Zentrum München, Deutsches Forschungszentrum für Gesundheit und Umwelt (42-46). Statistical analyses were performed using the R statistical software package (45).

Approval of research review board. The study was approved by the local ethics committee (Consent of Research Review Board at the Medical University of Lodz, Poland, No RNN/133/09/KE). At the commencement of the study, the participants were invited to attend voluntarily. Prior to enrollment, written informed consent was obtained from all patients.

\section{Results}

The frequencies of the genotypes of the NR3C1 gene Tth111I polymorphism in the control group were estimated: the frequencies of GG, AG and AA were estimated as 0.297, 0.632 and 0.071 , respectively. In the asthma population, the respec- 
Table IV. Comparative analysis of NR3C1 gene Tth111 I polymorphism frequency in healthy controls vs. patients with asthma characterized by a control profile corresponding to an $\mathrm{ACT}^{\mathrm{TM}}$ score $\geq 20$.

\begin{tabular}{|c|c|c|c|c|c|c|}
\hline & $\begin{array}{l}\text { Healthy controls } \\
\mathrm{n} \text { (expected) }\end{array}$ & $\begin{array}{c}\text { Asthma } \text { ACT }^{\mathrm{TM}} \text { score } \geq 20 \\
\text { n (expected) }\end{array}$ & OR & CI & $\mathrm{Chi}^{2}$ & P-value \\
\hline GG & $64(81.04)$ & $33(31.84)$ & & & & \\
\hline $\mathrm{AG}$ & $136(101.92)$ & $44(46.32)$ & & & & \\
\hline $\mathrm{AA}$ & $15(32.04)$ & $18(16.84)$ & & & & \\
\hline$[\mathrm{AG}]$ vs. $[\mathrm{GG}]$ & & & 0.270 & $0.125-0.579$ & 12.25 & 0.00047 \\
\hline [AA] vs. [GG] & & & 0.430 & $0.192-0.960$ & 4.35 & 0.03699 \\
\hline [AA] vs. $[\mathrm{AG}+\mathrm{GG}]$ & & & 0.321 & $0.154-0.668$ & 9.93 & 0.00163 \\
\hline
\end{tabular}

The tests for association are adapted from Sasieni $(42,43)$. OR, odds ratio; CI, confidence interval; ACT ${ }^{\mathrm{TM}}$, Asthma Control Test.

tive frequencies were $0.349,0.534$ and 0.117 , and a higher frequency of the Tth111I polymorphism AA homozygote and lower frequency of the AG heterozygote in comparison with the control group were observed.

The estimated genotype frequencies of the NR3Cl gene $B c l$ I polymorphism in the control group were determined; the frequencies of GG, GC and CC were 0.292, 0.592 and 0.116 , respectively. In the asthma population, the respective frequencies were $0.282,0.577$ and 0.141 , and a lower frequency of the $\mathrm{Bcl}$ I polymorphism GG homozygote and a higher frequency of the CC homozygote were observed in comparison with the control group.

The genotype frequencies of the NR3C1 gene ER22/23EK polymorphism were estimated in the control group; the frequencies of GG, GA and AA were estimated as 0.935, 0.065 and 0.000 , respectively. In asthma patients, the respective frequencies were observed to be $0.944,0.056$ and 0.000 , and a higher frequency of the ER22/23EK polymorphism GG homozygote and a lower frequency of the GA heterozygote were observed in comparison with the control group. No AA homozygotes of the studied SNP were observed.

The consistency of genotype distribution in the control and asthma groups with Hardy-Weinberg equilibrium was demonstrated only for the ER22/23EK SNP of the NR3C1 gene.

No statistically significant differences were observed in the frequencies of the Tth111I, BclI and ER22/23EK polymorphisms of the $\mathrm{NR} 3 \mathrm{Cl}$ gene when mild, moderate, and severe asthma were compared against the control group ( $\mathrm{p}>0.05)$.

Statistically significant differences were identified in the distribution of Tth111I polymorphism of the NR3C1 gene between asthma patients stratified according to asthma control levels based on $\mathrm{ACT}^{\mathrm{TM}}$ scores ( $<20$ vs. $\geq 20$; $\mathrm{p}<0.05$ ). Table III shows the distribution of genotype frequencies for Tth111I polymorphism among asthma patients taking into consideration the disease control level based on $\mathrm{ACT}^{\mathrm{TM}}$ scores ( $<20$ vs. $\geq 20$ ).

No statistically significant differences were noted in the distribution of genotype frequencies for $B c l$ I and ER22/EK23 polymorphisms of the $N R 3 C l$ gene between the populations of asthma patients taking into consideration the disease control level based on $\mathrm{ACT}^{\mathrm{TM}}$ score ( $<20$ vs. $\geq 20$; $\mathrm{p}>0.05$ ). The results in this study did not confirm previous observations on the role of $B c l$ I polymorphism of $N R 3 C l$ gene in the pathogenesis of asthma. A $B c l$ I SNP pilot study was carried out on a small number of patients and controls. This confirms the need for genetic testing in a larger number of cases (47).It is worth noting that the current study highlights the lack of association between polymorphic forms ER22/23EK of NR3C1 gene in the pathogenesis of asthma, as noted by the authors in a previous study with a similar sample size (48).

In view of the results obtained for Tth111I polymorphism of the NR3Cl gene in asthma patients, additional exploration analyses were carried out within that group. The trends for potential correlations within the patient population were identified by considering the disease control level according to $\mathrm{ACT}^{\mathrm{TM}}$ score and the disease severity according to GINA criteria. The correlations between the frequencies of alleles and genotypes in the patient population and in the controls were evaluated.

Additional analyses addressing the frequencies of $\mathrm{NR} 3 \mathrm{Cl}$ gene Tth111I polymorphism alleles and genotypes demonstrated statistically significant correlations between healthy controls and patients with asthma characterized by a control profile corresponding to an $\mathrm{ACT}^{\mathrm{TM}}$ score $\geq 20$, as shown in Table IV.

Exploration analyses demonstrated statistically significant correlations for alleles and genotypes of the Tth111I polymorphism of the $N R 3 C 1$ gene between healthy subjects and patients with severe asthma characterized by a control profile corresponding to an $\mathrm{ACT}^{\mathrm{тм}}$ score $\geq 20$, between healthy subjects and patients with non-allergic severe asthma characterized by a control profile corresponding to an $\mathrm{ACT}^{\mathrm{TM}}$ score $\geq 20$, and between healthy subjects and patients with allergic severe asthma characterized by a control profile corresponding to an $\mathrm{ACT}^{\mathrm{TM}}$ score $\geq 20$, as shown in Tables V, VI and VII, respectively.

\section{Discussion}

The present study concerns a new aspect of the role of genetic factors in the complex etiopathogenesis of chronic bronchitis and bronchial asthma, which approaches asthma in a multidimensional manner. The study proposes a novel strategic approach for assessing the effect of hereditary variables in the disease. The first dimension comprises genetic factors (gene polymorphisms); the second, the severity of the disease (assessed on the basis of the GINA report criteria: mild, moderate or severe); and the third, asthma symptom control level (assessed individually by the patients on the basis of $\mathrm{ACT}^{\mathrm{TM}}$ score). 
Table V. Comparative analysis of $\mathrm{NR3Cl}$ gene Tth111I polymorphism frequency in healthy controls vs. patients with severe asthma characterized by a control profile corresponding to an ACT $^{\text {TM }}$ score $\geq 20$.

\begin{tabular}{lcccccc}
\hline & $\begin{array}{c}\text { Severe asthma } \\
\text { Healthy controls } \\
\text { n (expected) }\end{array}$ & $\begin{array}{c}\text { ACT } \\
\mathrm{n} \text { (expected) }\end{array}$ & OR & CI & Chi $^{2}$ & P-value \\
\hline GG & $64(81.04)$ & $8(5.76)$ & & & & \\
$\mathrm{AG}$ & $136(101.92)$ & $6(10.48)$ & & & & \\
$\mathrm{AA}$ & $15(32.04)$ & $7(4.76)$ & & & & \\
{$[\mathrm{AG}]$ vs. $[\mathrm{GG}]$} & & & 0.095 & $0.028-0.318$ & 19.87 & $8.23 \mathrm{e}-06$ \\
{$[\mathrm{AA}]$ vs. $[\mathrm{GG}]$} & & & 0.268 & $0.084-0.854$ & 5.39 & 0.02028 \\
{$[\mathrm{AA}]$ vs. $[\mathrm{AG}+\mathrm{GG}]$} & & & 0.150 & $0.053-0.428$ & 15.72 & 0.00007 \\
\hline
\end{tabular}

The tests for association are adapted from Sasieni $(42,43)$. OR, odds ratio; CI, confidence interval; ACT $^{\mathrm{TM}}$, Asthma Control Test.

Table VI. Comparative analysis of $N R 3 C 1$ gene Tth111I polymorphism frequency in healthy controls vs. patients with severe non-allergic asthma characterized by control profile corresponding to $\mathrm{ACT}^{\mathrm{TM}}$ score $\geq 20$.

\begin{tabular}{|c|c|c|c|c|c|c|}
\hline & $\begin{array}{l}\text { Healthy controls } \\
\mathrm{n} \text { (expected) }\end{array}$ & $\begin{array}{l}\text { Severe non-allergic asthma } \\
\text { ACT }^{\mathrm{TM}} \text { score } \geq 20 \\
\text { n (expected) }\end{array}$ & OR & CI & $\mathrm{Chi}^{2}$ & P-value \\
\hline GG & $64(81.04)$ & $4(2.25)$ & & & & \\
\hline $\mathrm{AG}$ & $136(101.92)$ & $1(4.50)$ & & & & \\
\hline AA & $15(32.04)$ & $4(2.25)$ & & & & \\
\hline [AG] vs. [GG] & & & 0.028 & $0.003-0.263$ & 22.21 & $2.440 \mathrm{e}-06$ \\
\hline$[\mathrm{AA}]$ vs. $[\mathrm{AA}+\mathrm{GG}]$ & & & 0.094 & $0.023-0.386$ & 15.62 & 0.00008 \\
\hline
\end{tabular}

The tests for association are adapted from Sasieni $(42,43)$. OR, odds ratio; CI, confidence interval; ACT ${ }^{\mathrm{TM}}$, Asthma Control Test.

Table VII. Comparative analysis of NR3C1 gene Tth111I polymorphism frequency in healthy controls vs. patients with severe allergic asthma characterized by a control profile corresponding to an $\mathrm{ACT}^{\mathrm{TM}}$ score $\geq 20$.

\begin{tabular}{|c|c|c|c|c|c|c|}
\hline & $\begin{array}{l}\text { Healthy controls } \\
\mathrm{n} \text { (expected) }\end{array}$ & $\begin{array}{l}\text { Severe allergic asthma } \\
\text { ACT }^{\mathrm{TM}} \text { score } \geq 20 \\
\text { n (expected) }\end{array}$ & OR & CI & $\mathrm{Chi}^{2}$ & P-value \\
\hline GG & $64(81.04)$ & $4(3.52)$ & & & & \\
\hline $\mathrm{AG}$ & $136(101.92)$ & $5(5.96)$ & & & & \\
\hline AA & $15(32.04)$ & $3(2.52)$ & & & & \\
\hline$[\mathrm{AG}]$ vs. $[\mathrm{GG}]$ & & & 0.184 & $0.040-0.847$ & 5.75 & 0.01648 \\
\hline$[\mathrm{AA}]$ vs. $[\mathrm{AG}+\mathrm{GG}]$ & & & 0.225 & $0.055-0.920$ & 5.06 & 0.02453 \\
\hline
\end{tabular}

The tests for association are adapted from Sasieni $(42,43)$. OR, odds ratio; CI, confidence interval; ACT $^{\mathrm{TM}}$, Asthma Control Test.

It should be emphasized that the concept of a multidimensional approach to disease was first introduced when the system of classification of mental and behavioral disturbances, DSM IV, was being developed. At that time, the multidimensional approach was applied to the categorization of schizophrenia symptoms during the development of the positive and negative syndrome scale (PANSS) $(46,49)$. This approach is increasingly widely used in the classification of somatic disorders, as exemplified by the updated version of the GOLD 2011 report $(49,50)$.

The studied populations were imbalanced with respect to $B c l$ I and Tthl11I polymorphisms, which may be explained by the lethal character of changes in nucleotide variances of the analyzed $\mathrm{NR} 3 \mathrm{Cl}$ gene. Another potential reason for disequilibrium in genotype distribution may be non-random selection of sexual partners. As partners are selected on the basis of 
certain characteristics, the distribution of genotypes in the population deviates from equilibrium.

No differences in the frequencies of $B c l I$ and ER22/23EK polymorphisms of the $N R 3 C l$ gene between asthma patients and healthy controls were observed. No correlation was found between the frequencies of $B c l$ I and ER22/23EK $N R 3 C 1$ gene polymorphisms and asthma control level in the patient group.

However, the study demonstrated a correlation between the presence of the Tth111I polymorphism of the NR3Cl gene and a specific profile of asthma control according to $\mathrm{ACT}^{\mathrm{TM}}$. Additionally, correlations were demonstrated between the presence of the Tth111I NR3Cl gene polymorphism in the patient group and the disease severity and higher asthma control level based on $\mathrm{ACT}^{\mathrm{TM}}$ scores. Correlations were noted between the frequency of Tth111I SNP alleles in the population of asthma patients with disease control profiles corresponding to an $\mathrm{ACT}^{\mathrm{TM}}$ score $\geq 20$ and healthy controls.

Allele A of the Tth111I NR3Cl gene polymorphism was demonstrated to be an important factor correlating with the risk of development for specific disease phenotypes (severe asthma with $\mathrm{ACT}^{\mathrm{TM}}$ score $\geq 20$, severe non-allergic asthma with $\mathrm{ACT}^{\mathrm{Tm}}$ score $\geq 20$ and severe allergic asthma with $\mathrm{ACT}^{\mathrm{Tm}}$ score $\geq 20$ ). The expression ratio of two A alleles of the analyzed SNP was found to be the determinant most strongly correlated with higher control levels of severe asthma, both allergic and non-allergic. For the above analyses, high statistical significance levels were observed, which confirms the role of Tth111I NR3Cl gene polymorphism in the pathogenesis of specific disease phenotypes.

Therefore, it appears that the correct approach to the analysis of the role of SNPs in the etiology of pulmonary diseases is a multifactorial interpretation of the function of NR3C1 gene polymorphisms in the pathogenesis of obstructive syndromes. According to this approach to asthma, the significance of only one of the analyzed SNPs (Tth111I) has been demonstrated. The site of the Tth111I polymorphism is located in the intron close to the initiation site and $3807 \mathrm{pb}$ above the first site where transcription starts in exon 2 . It causes $\mathrm{G}>\mathrm{A}$ substitution in the promoter region, and is also associated with ER22/23EK SNP localized in exon 2 of the NR3Cl gene $(25,28)$. It is noteworthy that a G-13-6284A type SNP in this NR3C1 gene domain may affect, in combination with ER22/23EK, structural changes in the A/B region of the GCR and functional changes within the AF1 functional domain, which influences the GCR activity and enables interaction with numerous transcriptional factors $(4,6,24,27,29)$.

The current study is an important part of a campaign aimed at the prevention of asthma (especially severe asthma) as well as early diagnosis, planning of therapy adjusted to the patient's requirements, and improvement of care for patients with uncontrolled symptom profiles. Thus, there are important prerequisites to develop a research technique using Tth111I as a diagnostic marker of cases requiring individual glucocorticosteroid therapy. Evaluation of its applicability in this area requires further investigation.

In conclusion, the concept of asthma endotype separation as a new approach to classification of disease occurs more often in genetic screening according to data provided by the NCBI. Intermediate phenotypes of asthma are morphologi- cally or functionally defined. This approach is based on the molecular mechanism or response to treatment.

It was established that the Tth111I polymorphism of the $N R 3 C 1$ gene plays an important role in the pathogenesis of chronic bronchitis leading to the development of asthma with both allergic and non-allergic etiology. This SNP correlates significantly with the severe asthma phenotype characterized by a control profile corresponding to an $\mathrm{ACT}^{\mathrm{TM}}$ test score $\geq 20$.

Polymorphism Tth111I of the NR3C1 gene differentiates asthma patients according to the symptom control level based on the $\mathrm{ACT}^{\mathrm{TM}}$ test score into two subpopulations $\left(\mathrm{ACT}^{\mathrm{TM}}\right.$ score $<20$ vs. ACT ${ }^{\mathrm{TM}}$ score $\geq 20$ ).

In conclusion, homozygote AA Tth111I correlates with a more moderate course of the disease and a higher control level of its symptoms.

\section{Acknowledgements}

The authors wish to thank Grzegorz Uraziński, M.Sc.Eng. in Architecture, for preparation of the figures and his kind assistance in graphic rendering of research materials.

The study was partially financed by Grant No N N402 374638 of the Minister of Science and Higher Education of the Polish Republic received by Michał Panek, MD and Professor Piotr Kuna. The study was partially financed by a grant received by Michał Panek, MD, within the framework of a project supporting innovative doctoral studies, entitled: 'Scholarships supporting innovative doctoral studies' based on funds provided by the EU European Social Fund and Polish state budget allocation for Integrated Operational Plan for Regional Development according to Lodz Region Innovation Strategy - RSI LORIS. Program title: ZPORR. Sector: 2.6 Regional Innovation Strategies and Transfer of Knowledge. Project title: 'Scholarships supporting innovative doctoral studies'. Project number: Z/2.10/II/2.6/1/09. The project receives $75 \%$ of its funding from the European Social Fund and $25 \%$ from the state budget. The study was also financed by funds No. 503/1-095-03/503-01 from the Department of Internal Medicine, Asthma and Allergy, 2nd Chair of Internal Medicine, Medical University of Lodz, Poland.

\section{References}

1. Global Initiative for Asthma 2007: GINA executive summary. Eur Respir J 31: 143-178, 2008.

2. National Institutes of Health: Guidelines for the Diagnosis and Management of Asthma. National Asthma Education and Prevention Program (NAEPP) Expert Panel Report 3. Summary Report 2007. NIH Publication Number 08-5846. National Institutes of Health, National Heart, Lung and Blood Institute, Bethesda, MD, 2007.

3. Wenzel S: Asthma: defining of the persistent adult phenotypes. Lancet 368: 804-813, 2006.

4. Droszcz W (ed): Astma. Wydawnictwo Lekarskie PZWL, Warsaw, 2007 (In Polish).

5. Kino T, De Martino M, Charmandari E, et al: Tissue glucocorticoid resistance/hypersensitivity syndromes. J Steroid Biochem Mol Biol 85: 457-467, 2003.

6. Derijk R and de Kloet E: Corticosteroid receptor polymorphisms: determinants of vulnerability and resilience. Eur J Pharmacol 583: 303-311, 2008.

7. Bamberger C, Bamberger A, de Castro M, et al: G. Glucocorticoid receptor beta, a potential endogenous inhibitor of glucocorticoid action in humans. J Clin Invest 95: 2435-2441, 1995. 
8. Ito K, Chung $\mathrm{K}$ and Adcock I: Update on glucocorticoid action and resistance. J Allergy Clin Immunol 117: 522-543, 2006.

9. DeRijk R, Schaaf M and de Kloet E: Glucocorticoid receptor variants: clinical implications. J Steroid Biochem Mol Biol 81: 103-122, 2002

10. Grzanka A and Rogala B: Molecular mechanism of glucocorticoids and difficult asthma. Allerg Asthma Immunol 5: 247-252, 2000.

11. Panek M, Pietras T, Antczak A, et al: The N363S and I559N single nucleotide polymorphisms of the h-GR/NR3C1 gene in patients with bronchial asthma. Int J Mol Med 30: 142-150, 2012

12. Adcock IM, Ford P, et al: Steroid resistance in asthma: mechanisms and treatment options. Curr Allergy Asthma Rep 8: $171-178,2008$

13. Barnes P: Molecular mechanisms of glucocorticoid action in asthma. Pulm Pharmacol Ther 10: 3-19, 1997.

14. Panek M, Pietras T, Kupryś-Lipińska I, et al: The analysis of the factors influencing the development of glucocorticoid resistance in the etiopathogenesis of severe bronchial asthma. Postepy Biochem 56: 373-382, 2010 (In Polish).

15. Leung D and Bloom J: Update on glucocorticoid action and resistance. J Allergy Clin Immunol 111: 3-22, 2003.

16. Russcher H, Dalm V, de Jong F, et al: Associations between promoter usage and alternative splicing of the glucocorticoid receptor gene. J Mol Endocrinol 38: 91-98, 2007.

17. Van der Velden V: Glucocorticoids: mechanisms of action and anti-inflammatory potential in asthma. Mediators Inflamm 7: 229-237, 1998

18. Beato M, Chalepakis G, Schauer M, et al: DNA regulatory elements for steroid hormones. J Steroid Biochem Mol Biol 32 : 737-747, 1989.

19. Thomas $M$ and Chiang $C$ : The general transcription machinery and general cofactors. Crit Rev Biochem Mol Biol 41: 105-117, 2006.

20. Smale $\mathrm{S}$ and Kadonaga J: The RNA polymerase II core promoter. Annu Rev Biochem 72: 449-479, 2003.

21. Wu S and Chiang C: TATA-binding protein-associated factors enhance the recruitment of RNA polymerase II by transcriptional activators. J Biol Chem 276: 34235-34243, 2001

22. Bulas M, Trelińska J, Stolarska M, et al: Association of steroid receptor gene $(\mathrm{NR} 3 \mathrm{Cl}$ ) polymorphism with clinical course of lymphoproliferative disorders in children - preliminary results Onkol Pol 2: 77-81, 2008 (In Polish).

23. Bulas M, Pierlejewski F and Młynarski W: Glucocorticosteroid resistance in lymphoproliferative diseases in children. Przegląd Pediatryczny 1: 57-61, 2009 (In Polish).

24. Van Rossum E and Lamberts S: Polymorphisms in the glucocorticoid receptor gene and their associations with metabolic parameters and body composition. Recent Prog Horm Res 59: 333-357, 2004.

25. Nicolaides N, Galata Z, Kino T, et al: The human glucocorticoid receptor: molecular basis of biologic function. Steroids 75: 1-12, 2010

26. Bray $\mathrm{P}$ and Cotton R: Variations of the human glucocorticoid receptor gene $(\mathrm{NR} 3 \mathrm{C} 1)$ : pathological and in vitro mutations and polymorphisms. Hum Mutat 2003 21: 557-568.

27. Mwinyi J, Wenger C, Eloranta J and Kullak-Ublick G: Glucocorticoid receptor gene haplotype structure and steroid therapy outcome in IBD patients. World J Gastroenterol 16: 3888-3896, 2010

28. Van Rossum E, Koper J, van den Beld A, et al: Identification of the BclI polymorphism in the glucocorticoid receptor gene: association with sensitivity to glucocorticoids in vivo and body mass index. Clin Endocrinol 59: 585-592, 2003.

29. Buemann B, Vohl M, Chagnon M, et al: Abdominal visceral fat is associated with a BclI restriction fragment length polymorphism at the glucocorticoid receptor gene locus. Obes Res 5: 186-192, 1997.
30. Panarelli M, Holloway C, Fraser R, et al: Glucocorticoid receptor polymorphism, skin vasoconstriction and other metabolic intermediate phenotypes in normal subjects. J Clin Endo Met 83: 1846-1852, 1998

31. De Iudicibus S, Franca R, Martelossi S, et al: Molecular mechanism of glucocorticoid resistance in inflammatory bowel disease. World J Gastroenterol 17: 1095-1108, 2011.

32. De Lange P, Koper J, Huizenga N, et al: Differential hormone-dependent transcriptional activation and repression by naturally occurring human glucocorticoid receptor variants. Mol Endocrinol 11: 1156-1164, 1997.

33. Miller M, Hankinson J, Brusasco V, et al: Standardisation of Spirometry. Eur Respir J 26: 319-338, 2005.

34. Nathan R, Sorkness C, Kosinski M, et al: T. Development of the test: a survey for assessing asthma control. J Allergy Clin Immunol 113: 59-65, 2004.

35. Dreborg S, Backman A and Bosomba A: Skin tests used in type I allergy testing. Position paper. Sub-Committee on Skin Tests of the European Academy of Allergology and Clinical Immunology. Allergy 44: 1-59, 1989.

36. Wittwer CT: High-resolution DNA melting analysis: advancements and limitations. Hum Mutat 30: 857-859, 2009

37. Vossen RH, Aten E, Roos A, et al: High-resolution melting analysis (HRMA) - more than just sequence variant screening. Hum Mutat 30: 860-866, 2009.

38. Tindall EA, Petersen DC, Woodbridge P, et al: Assessing high-resolution melt curve analysis for accurate detection of gene variants in complex DNA fragments. Hum Mutat 30: 876-883, 2009.

39. Lyon $\mathrm{E}$ and Wittwer CT: LightCycler technology in molecular diagnostics. J Mol Diagn 11: 93-101, 2009.

40. Dobrowolski SF, Gray J, Miller T, et al: Identifying sequence variants in the human mitochondrial genome using high-resolution melt (HRM) profiling. Hum Mutat 30: 891-898, 2009

41. Szabó V, Borgulya G, Filkorn T, et al: The variant N363S of glucocorticoid receptor in steroid-induced ocular hypertension in Hungarian patients treated with photorefractive keratectomy. Mol Vis 13: 659-666, 2007.

42. Institute of Human Genetics: Case-control studies. Tests for deviation from Hardy-Weinberg equilibrium and tests for association. http://ihg.gsf.de

43. Sasieni PD: From genotypes to genes: doubling the sample size. Biometrics 53: 1253-1261, 1997.

44. Weir BS: Statistical Data Analysis II. Methods for Discrete Population Genetic Data. 2nd edition. Sinauer Associates., Inc., Sunderland, MA, USA, pp 91-140, 1996.

45. R Development Core Team: R: a language and environment for statistical computing. R Foundation for Statistical Computing, Vienna, 2011, http://www.R-project.org.

46. Andreasen N and Olsen S: Negative vs. positive schizophrenia: definition and validation. Arch Gen Psychiatry 39: 789-794, 1982.

47. Pietras T, Panek M, Tworek D, et al: The Bcl I single nucleotide polymorphism of the human glucocorticoid receptor gene h-GR/NR3C1 promoter in patients with bronchial asthma: pilot study. Mol Biol Rep 38: 3953-3958, 2011.

48. Panek M, Pietras T, Antczak A, et al: The role of functional single nucleotide polymorphisms of the human glucocorticoid receptor gene NR3C1 in Polish patients with bronchial asthma. Mol Biol Rep 39: 4749-4757, 2012.

49. Panek M, Pietras T and Kuna P. Contemporary management of COPD in the view of the new GOLD guidelines. Terapia 271: 71-77, 2012.

50. The Global Initiative for Chronic Obstructive Lung Disease (GOLD). Available from URL: http:// http://www.goldcopd.org. 